\title{
Effect of Physical Exercise on some Hematological Parameters in Female Athletes in Bangladesh
}

\author{
Tanbira Alam, ${ }^{1}$ S M Niazur Rahman, ${ }^{2}$ Tanjeda Alam, ${ }^{3}$ Nasrin Habib, ${ }^{1}$ Badar Uddin Umar, ${ }^{4}$ Quazi Rubayth Banna, ${ }^{4}$ Lubna \\ Shirin, ${ }^{2}$ Rokeya Begum ${ }^{5}$ \\ ${ }^{1}$ Physiology Unit, ${ }^{2}$ Anatomy Unit, ${ }^{4}$ Pharmacology Unit, AIMST University, Semeling, Bedong, Kedah, Malaysia, ${ }^{3}$ Malaysia \\ Health Care Services Ltd. Banani, Dhaka, Bangladesh, ${ }^{5}$ Department of Physiology, Enam medical college, Savar, Bangladesh.
}

\section{ABSTRACT}

Introduction: Long term physical training has been considered to adversely affect the performance of athletes especially the females. It may be due to the iron depletion caused by hemolysis or hemodilution results from plasma volume expansion. This study aims to assess the effect of heavy exercise on hemoglobin concentration and some other hematological parameters in female athletes.

Methods: This cross sectional study was carried out in the Department of physiology, Dhaka Medical College, Dhaka, from July 2010-June 2011. A total number of 105 females (70 athletes and 35 non athletes) between 15-25 years of age were recruited. The 35 apparently healthy female non athletes were taken as control (Group-A) and 70 female athletes comprise the study group (Group-B). According to sporting category, Group-B was further subdivided as B1:Runners and B2:Cyclists. Hemoglobin percentages $(\mathrm{Hb} \%)$, red blood cell (RBC) concentration, packed cell volume (PCV), serum iron, serum ferritin and total iron binding capacity (TIBC) were measured in fasting state after two months training. Statistical analysis was done by using SPSS/ win.15.0 for comparison between the groups, using student's unpaired " $\mathrm{t}$ " test.

Results: Mean $\mathrm{Hb} \%, \mathrm{RBC}, \mathrm{PCV}$, iron and ferritin level were significantly $(\mathrm{P}<0.001)$ lower in athletes than those of control group. Within the study groups, runner's serum iron and ferritin level were lower than cyclists. TIBC significantly $(\mathrm{P}<0.001)$ rose in Group-B2 in comparison to Group-A.

Conclusion: The current study showed that intense physical exercise leads to early stages of $\mathrm{Hb} \%$, $\mathrm{RBC}, \mathrm{PCV}$, iron and ferritin depletion which might compromise the health and performance of athletes.

Keywords: exercise; hemoglobin; packed cell volume; serum iron.

\section{INTRODUCTION}

Physical performance is dependent on the hematological parameters. Red cell mass decrement has negative effect on physical exercise capacity. ${ }^{1,2}$ Iron deficiency anemia is the most prevalent micronutrient deficiency in the world population. ${ }^{3-5}$ About $16 \%$ women aged between 12-49 years have iron deficiency in the United States. ${ }^{6}$ When there is an imbalance between iron intake and iron excretion, iron deficiency anemia can be resulted. ${ }^{7}$ Evidences of professional athletes developing anemia

Correspondence: Dr. Tanbira Alam, Faculty of Medicine, AIMST University, Semeling, Bedong, Kedah, Malaysia. Email: alamtanbira@ gmail.com Mobile: +60164255905 . 
are abundant. ${ }^{8-10}$ Several studies have documented higher number of the female athletes having iron deficiency. ${ }^{11-12}$ Ahmadi et al. $(2010)^{3}$ have reported the prevalence of iron deficiency in male and female athletes to be $10 \%$ and $20 \%$, respectively. Among many causes for anemia in female athletes, ${ }^{2}$ erythrocyte destruction, exercise stress and decreased erythropoietin production are best to mention. ${ }^{3,{ }^{13}}$ Athletes doing intense exercise are at greater risk for iron deficiency. ${ }^{14}$ Athletes may loss iron via several routes such as bleeding and sweating as well as menstrual cycle in female athletes. ${ }^{3-4,15}$ Iron plays a key role in number of cellular processes, such as DNA synthesis and electron transport. Furthermore it is an essential element of $\mathrm{Hb}$, the blood oxygen carrier. By these means, iron depletion can affect physical performance. $^{16}$

Very low or depleted iron stores reduced red blood cell count and hemoglobin values and make it difficult to transport oxygen in to the cells. ${ }^{3-4,17}$ Increased red cell destruction ${ }^{2}$ have been reported during early phases of training which could lead to a negative iron balance. ${ }^{18}$ Proposed mechanisms for development of iron deficiency in athletes are - gastrointestinal blood loss due to running, traumatic hematuria, increased RBC turnover, exercise related iron absorption disorders. ${ }^{12}$ Mechanisms for decreased RBC mass could be intravascular hemolysis by mechanical rupture while passing through capillaries in contracting muscles as well compression during foot strike during running. ${ }^{8}$ Runners have a greater need for iron than endurance athletes in other sports, e.g., swimming and cycling. ${ }^{17}$

Females being a major part of the population and contributor in every aspects of development of a country should receive greater importance in health as well as fitness. It is important to know about their nutritional status and the impact of deficiencies of particular nutritional elements on their health and performance. So, we conducted this study to find out the iron status of Bangladeshi female athletes and its effects on different hematological parameters.

\section{METHODS}

This observational cross sectional study was carried out in the Department of Physiology, Dhaka Medical College, Dhaka, from July 2010 to June 2011. One hundred five females of same age group (15-25 years) were included as study subjects ( 70 athletes and 35 non athletes). Thirty five apparently healthy female non athletes were included as control group (GroupA). The study group (Group- B) comprising of 70 female athletes was selected according to sporting category and was further subdivided as Group-B1 (runners) and Group-B2 (cyclists). The Group-A subjects were never engaged in any types of exercise and were selected from students of Dhaka University. The Group-B subjects were selected from students of Sultana Kamal Women Sports Complex (SKWC), Dhaka.

All the subjects were briefed about the purpose of the study in a cordial way explaining the benefits they would avail from the study. They were encouraged to participate voluntarily. They were also allowed to withdraw any time they wish. An informed written consent was obtained from the participants. On completion of two months training the fasting venous blood samples were collected for estimation of $\mathrm{Hb} \%, \mathrm{RBC}$ concentration, PCV, serum iron level, serum ferritin and total iron binding capacity (TIBC). All the anthropometric measurements were taken after evacuation of bladder \& bowel. By using SPSS/ win. 15.0 comparison between the groups were done, using student's unpaired " $\mathrm{t}$ " test.

Table-1. Hemoglobin level (Hb \%), RBC and PCV in athletes and no

\begin{tabular}{|llll|}
\hline Groups & Mean \pm SD Hb\% $(\mathrm{gm} / \mathrm{dl})$ & Mean \pm SD RBC $\left(\mathrm{mm}^{3}\right)$ & Mean \pm SD PCV (\%) \\
A $(n=35)$ & $12.41 \pm 0.88$ & $4.25 \pm 0.39$ & $39.75 \pm 2.64$ \\
B1 $(n=35)$ & $9.91 \pm 1.18$ & $3.52 \pm 0.50$ & $27.63 \pm 4.21$ \\
B2 $(n=35)$ & $9.73 \pm 0.83$ & $3.91 \pm 0.29$ & $29.40 \pm 3.08$ \\
A vs B1 & $P<0.001^{*}$ & $P<0.001^{*}$ & $P<0.001^{*}$ \\
A vs B2 & $P<0.001^{*}$ & $P<0.001^{*}$ & $P<0.001^{*}$ \\
B1 vs B2 & $P$ P0.05 & $P<0.001^{*}$ & $P<0.05^{\dagger}$ \\
\hline
\end{tabular}

$\begin{array}{ll}\text { Group A: } & \text { Non-athlete } \\ \text { Group B1: } & \text { Runner } \\ \text { Group B2: } & \text { Cyclist } \\ * \quad= & \text { Significant at } P<0.001 \\ \dagger \quad= & \text { Significant at } P<0.05 \\ \ddagger & \text { Not significant }\end{array}$


Alam et al. Effect of Physical Exercise on Some Hematological Parameters in Female Athletes in Bangladesh

\begin{tabular}{|c|c|c|c|}
\hline Groups & $\begin{array}{l}\text { Mean } \pm \text { SD Serum Iron } \\
(\mu \mathrm{g} / \mathrm{dl})\end{array}$ & $\begin{array}{l}\text { Mean } \pm \text { SD Serum } \\
\text { Ferritin }(\mathrm{ng} / \mathrm{ml})\end{array}$ & Mean \pm SD TIBC $(\mu \mathrm{g} / \mathrm{dl})$ \\
\hline$A(n=35)$ & $77.56 \pm 5.00$ & $43.47 \pm 2.16$ & $373.40 \pm 12.24$ \\
\hline B1 $(n=35)$ & $57.69 \pm 22.35$ & $20.62 \pm 19.76$ & $394.14 \pm 68.01$ \\
\hline B2 $(n=35)$ & $76.09 \pm 34.90$ & $25.71 \pm 23.22$ & $416.51 \pm 66.44$ \\
\hline$A$ vs $B 1$ & $\mathrm{P}<0.001^{*}$ & $\mathrm{P}<0.001^{*}$ & $\mathrm{P}\left[0.05^{\ddagger}\right.$ \\
\hline$A$ vs $B 2$ & Pप0.05 & $\mathrm{P}<0.001^{*}$ & $\mathrm{P}<0.001^{*}$ \\
\hline B1 vs B2 & $\mathrm{P}<0.05^{\dagger}$ & $P>0.05^{\ddagger}$ & $P>0.05^{\ddagger}$ \\
\hline
\end{tabular}

$\begin{array}{lll}\text { Group A: } & \text { Non-athlete } \\ \text { Group B1: } & \text { Runner } \\ \text { Group B2: } & \text { Cyclist } \\ * \quad= & \text { Significant at } P<0.001 \\ \dagger \quad= & \text { Significant at } P<0.05 \\ \ddagger & = & \text { Not significant }\end{array}$

RESULTS

The mean ( $\pm \mathrm{SD}) \mathrm{Hb} \%$ was significantly lower $(\mathrm{P}<0.001)$ in $\mathrm{B} 1$ and $\mathrm{B} 2$ groups than group-A. Though not significant statistically, group-B1 had higher level of $\mathrm{Hb}$ than group-B2 (Table-1). Mean ( $\pm \mathrm{SD}$ ) total RBC count was significantly lower $(P<0.001)$ in group $B 1$ and $B 2$ as compared to group $A$ (Table-1).PCV also showed the same trend. The mean ( \pm SD) PCV in group B1 and B2 was significantly lower than group-A, but group $B 2$ had significantly higher $(P<0.05)$ PCV than that of B1 (Table-1).

The mean $( \pm S D)$ serum iron in group $B 1$ was significantly lower than that of group $A(P<0.001)$. But there was no significant difference between group B2 and group $A$. Serum iron in group B1 was lower than that of group B2 $(P<0.05)$ (Table-2).

The mean $( \pm S D)$ serum ferritin in group $B 1$ and $B 2$ was lower than that of group $A(P<0.001)$. Serum ferritin in group B1 was lower than that of group B2, but the difference was not statistically significant (Table-2).

The mean $( \pm S D$ ) serum TIBC in group B1 was higher than that of group $A$ but statistically not significant. The mean $( \pm S D$ ) serum TIBC level in group B2 was significantly $(P<0.001)$ higher than that of group $A$. But no significant differences were observed between group B1 and group B2 (Table-2).

\section{DISCUSSION}

In the present study the mean $\mathrm{Hb} \%, \mathrm{RBC}$ count and PCV was significantly lower among the runners and cyclists than control group. Though the runners had slightly higher level of hemoglobin than the cyclists and the cyclists had significantly higher PCV than that of the runners. Similar findings were also observed in previous studies where endurance exercise leads to reduction in $\mathrm{Hb} \%, \mathrm{RBC}$ count and hematocrit. ${ }^{1,19-}$ ${ }^{20}$ Authors in these studies proposed exercise induced hemodilution or plasma expansion as the cause of the decreased levels. Some also mentioned foot strike hemolysis as the cause of decreased $\mathrm{Hb}$ level. ${ }^{1,3,19-20}$ Mairblurl $(2013)^{8}$ has implicated intravascular hemolysis of senescent RBCs while passing through capillaries in contracting muscles. This finding is also supported by other investigators. ${ }^{11}$ Roecker et al.(2005), ${ }^{12}$ described some additional factors like gastrointestinal blood loss in runners, traumatic hematuria, increased RBC turn over and iron absorption disorders due to exercise. Increased deformability of RBCs after exercise was also noted in some studies which may lead to hemolysis and reduction in $\mathrm{Hb} \% .{ }^{21-22}$ Zoller and Vogel $(2004)^{23}$ in their review mentioned intestinal blood loss as a factor in addition to exercise induced hemolysis leading to routine test abnormalities including hemoglobin level.

Opposite findings were also evident where increased levels of $\mathrm{Hb}, \mathrm{RBC}$ count and PCV were documented instead of declining values after endurance exercise. ${ }^{24-26}$ Some authors did not find any significant changes in the $\mathrm{Hb}, \mathrm{RBC}$ and PCV levels after exercise. ${ }^{27}$

Other major findings of this study was that mean serum iron level was significantly lower $(P>0.05)$ in runners than control group. The serum iron level in runners was also significantly $(P<0.05)$ lower than that of cyclists. Similar significant differences were also reported by researchers from different countries. ${ }^{4,24}$ Bourque et al.(1997), ${ }^{28}$ describes no change in serum iron, TIBC, 
percentage saturation of transferrin and haptoglobin levels after twelve weeks of endurance exercise in women.

In this study serum ferritin level was significantly lower $(P>0.05)$ in athletes when compared to control. The serum ferritin level in runner was lower than cyclist, but the difference was not statistically significant. Similar type of findings were also reported by the various investigators from different countries. ${ }^{16,23}$

Mean serum TIBC level in the present study was significantly higher $(P>0.01)$ in athletes when compared to that of control. As well the runners had lower serum TIBC than that of the cyclists, but the difference was not statistically significant. Similar type of findings was also reported by several investigators from different countries. ${ }^{14,16,20,29}$ There have been reports of falling levels of TIBC and other hematological parameters in female soccer players even after four weeks iron supplementation. ${ }^{30}$

Investigators suggested that Iron and especially ferritin, the iron storage protein was reduced in athletes. This was due to higher iron loss accompanied with altered intestinal absorption and increased loss through intestines, sweat and urine..$^{20,30}$

Female athletes have many additional risk factors for developing iron deficiency and anemia. This leads to reduced physical work capacity. Athletes have several risk factors for iron depletion and anemia due to poor nutritional intake of iron, hemolysis caused by repeated foot strikes, blood \& iron loss through menstruation, gastrointestinal bleeding and urinary tracts and loss of iron through sweating. Monthly blood loss through menstruation might lead to a further decreased in the related variables, such as $\mathrm{Hb}$, Hct, iron and ferritin.

Increased TIBC suggests an increased need for iron. As iron stores become depleted, the TIBC increased, the significant increase in TIBC and trend towards lower ferritin levels suggested that iron was been removed from storage for hemoglobin formation.

\section{CONCLUSIONS}

The present study revealed that serum iron and serum ferritin levels were lower in female athletes. Runners had lower serum iron level than that of cyclists. Serum TIBC level was higher in cyclist in comparison to runners.

In conclusion we suggest routine estimation of serum iron status and hematological parameters of female athletes to detect any depletion so that substitutive therapy could be initiated early, whenever necessary.

\section{ACKNOWLEDGMENTS}

Authors of this study are thankful to the authority of Sultana Kamal Women Sports Complex, Dhaka and players for their cordial cooperation during sample collection.

Also acknowledge Dr. Kazi Selim Anwar, senior lecturer, Faculty of Medicine, AIMST University, Malaysia for his valuable suggestions and guidance during writing and editing the manuscript.

\section{REFERENCES}

1. Schumacher YO, Schmid A, Grathowhl D, Bultermann D, Berg A. Hematological indices and iron status in athletes of various sports and performances. Med Sci Sports Exerc. 2002; 34(5): 869-875.

2. Portal S, Epstein M, Dubnov G. Iron deficiency and anemia in female athletes-cause and risks. Harefuah. 2003; 142(10): 698-703, 717.

3. Ahmadi A, Enayatizadeh N, Akberzadeh M, Asadi S, Tabatabaee SHR. Iron status in female athletes participating in Team Ball-Sports. Pak J of biol Sci. 2010; 13(2): 93-96.

4. Beard J and Tobin B. Iron Status and exercise. Am J Clin Nutr. 2000; 72: 594S-97S.
5. Deakin V. Iron depletion in athletes. In: Burke L and Deakin V, eds. Clinical Sports Nutrition (2nd ed.): Sydney, Australia; McGraw-Hill.2000. p. 273-311. paragraph.com.au/pdf/ books/clin-sp-nutr.pdf . Accessed on 10/06/2014 at 8:55am.

6. Karl JP, Lieberman HR, Cable SJ, Williams KW, Young AJ, McClung JP. Randomized, double-blind, placebo-controlled trial of an iron-fortified food product in female soldiers during military training: relations between iron status, serum hepcidin, and inflammation. Am J Clin Nutr. 2010; 92: 93-100.

7. Kang HS, Tastsuhuro. Effects of 4 weeks iron supplementation on hematological and immunological status in female soccer players. Asia Pac J Clin Nutr. 2004; 13(4): 353-58. 
8. Mairburl H. Red blood cells in sports: effects of exercise and training on oxygen supply by red blood cells. Front Physiol. 2013; 12(4): 332.

9. Dellavalle DM and Haas JD. Iron supplementation improves energetic efficiency in iron-depleted female rowers. Med Sci Sports Exerc. 2014; 46(6): 1204-15.

10. Roecker L, Meier-Buttermilch R, Brechtel L, Nemeth E, Ganz T. Eur J Appl Physiol. 2005; 95: 569-571.

11. Malczewska J, Raczynski G, Stupniciki R. Iron status in female endurance atletes and in non-athletes. Int J Sport NurExercMetab. 2000; 10(3): 260-276.

12. Dubnov G and Constantini NW. Prevalance of iron depletion and anemia in top-level basketball players. Int J Sport NutrMetab. 2004; 14(1): 30-7.

13. Chatard JC, Mujika I, Guy C, Lacour JR. Anemia and iron deficiency in athletes. Practical Recommendations for Treatment. Sport Med. 1999; 27(4): 229-40.

14. Pattini A, Schena F and Guidi GC. Serum ferritin and serum iron changes after cross country and roller ski endurance races. Eur J Appl Physiol. 1990; 61: 55-60.

15. Sandstr $\square \mathrm{m} \mathrm{G}, \mathrm{B} \square$ rjesson M, Rdjer S. Iron Defeciency in Adolescent Female Athletes-Is Iron Status Affected by Regular Sporting Activity? Clin Sport Med. 2012; 22(6): 495-500.

16. Shabkhiz F, Roshan DV, Mehmandoust S, Inanlou Z. The effect of 12 weeks continuous aerobic training on hematological parameters in old female rats. World J of Sports Sci. 2009; 2 (4): 2078-4727.

17. John L. Iron, nutrition and exercise. Am J Clin Nut. 2000; 72 (2): 503-674.

18. Jara V, Marcela GG, Ricardo S. Iron status in Spanish junior soccer and basketball players. Int J of Sports Sci. 2006; 2 (4): 57-68.

19. Moosavizadermonir. Effect of one period of training on hemoglobin, hematocrit and RBC of athlete girls. Ann Biol Res. 2011; 2(6): 642-644.
20. Wilkinson JG, Martin DT, Adams AA, Liebman M. Iron status in Cyclist During High-Intensity Interval Training and Recovery. Int J Sports Med. 2002; 23: 544-548.

21. Cakir-Atabek H, Atsak P, Gunduz N, Bor-Kucukatay M. Effects of resistance training intensity on deformability and aggregation of red blood cells. ClinHemorheolMicrocirc. 2009; 41: 251-261.

22. Kilic-ToprakE, Ardic F, Erken G, Unver-Kocak F, Kucukatay $\mathrm{V}$, Bor-Kucukatay M. Hemoreological responses to progressive resistance exercise training in healthy young males. Med SciMonit. 2012; 18(6): CR351-360.

23. Zollar $\mathrm{H}$ and Vogel W. Iron supplementations in Athletes First Do No Harm. Nutrition. 2004; 20: 615-19.

24. Choudhary S, Rajnee, Kumar B, Binawara K. Effects of exercise on serum iron, blood haemoglobin and cardiac efficiency. J Postgrad Med Inst. 2012; 26(1): 13-16.

25. Bobeuf F, Labonté M, Khalil A, Dionne IJ. Effects of Resistance Training on Hematological Blood Markers in Older Men and Women: A Pilot Study. Curr GerontolGeriat Res. 2009; 1-4. doi:10.1155/2009/156820.

26. Noushad S, Ahmed S, Jafri H, Sherwani SK. Effect of Exercise on Hematological Parameters: A Study on Trained versus Un-Trained Male Subjects. Pak J Life Sci. 2012; 10(1) 18-21.

27. Lippi G, Schena F, Salvagno GL, Aloe R, Banfi G, Guidi GC. Foot-strike haemolysis after a $60-\mathrm{km}$ ultramarathon. Blood Transf. 2012; 10: 377-83. DOI 10.2450/2012.0167-11.

28. Bourque SP, Pate RR, Branch JD. Twelve weeks of endurance exercise training does not affect iron status measures in women. J Am Diet Assoc. 1997; 97(10): 1116-21.

29. Deli CK and Fatouros IG, Koutedakis Y, Jamurtas AZ. Iron Supplementation and Physical Performance. 2013; accessed on 09/06/20014 at http://creativecommons.org/licenses/ by $/ 3.0$

30. Kang HS and Matsuo T. Effects of 4 weeks iron supplementation on hematological and immunological status in elite female soccer players. Asia Pac J Clin Nutr. 2004; 13(4): 353-58. 